\title{
STRATEGI PENGEMBANGAN RURAL TOURISM DI WILAYAH JAZIRAH LIEHITU: STUDY KASUS DESA TULEHU DAN DESA LIANG KECAMATAN SALAHUTU KABUPATEN MALUKU TENGAH
}

\author{
Maimunah Toatubun \\ Fakultas Syariah Jurusan Ekonomi Islam IAIN Ambon \\ Email: Maimunaht1963@gmail.com
}

\begin{abstract}
ABSTRAK
Penelitian ini bertujuan untuk: (1) Untuk mengindentifikasi dan menemu kenali potensi-potensi wisata yang dapat mendukung desa Tulehu dan desa Liang dalam menerapkan Strategy Rural Tourism; (2 ) Untuk mengetahui kesiapan Aparat dan jajaran Pemerintah Desa adat Tulehu dan Liang dalam memanfaatkan peluang penerapan UU Desa tahun 2014 tentang Desa sebagai sebuah landasan; dan kewenangan dalam mengembangkan Strategy Rural Tourism di wilayah mereka. (3) Untuk mengetahui tingkat dukungan dan keterlibatan komunitas lokal dalam mendukung Desa Tulehu dan Desa Liang dalam menerapkan Strategy Rural Tourism; (4) mengetahui persepsi para wisatawan lokal, nasional dan mancanegara tentang desa Tulehu dan desa Liang dalam rangka pengembangan Strategy Rural Tourism. Hasil penelitian menunjukan bahwa: (1) Desa Tulehu memiliki potensi wisata yang lebih siap dalam untuk menjadi desa wisata dibandingkan dengan desa Liang; (2) Kesiapan pemerintah desa Tulehu dalam pengelolaan desa wisata lebih siap dibandingkan dengan desa Liang; (3) Keterlibatan masyarakat dan komunitas di dua desa sangat bagus dalam pengelolaan desa wisata; (4) Persepsi wisatawan lokal dan nusantara terhadap pengelolaan obyek wisata di desa Tulehu dan Liang masih rendah.
\end{abstract}

Kata kunci: strategy, pengembangan, rural tourism

\begin{abstract}
The aim of research are to: (1) To identified and find out potensial and "capital" to developed stategy for Rural tourism in both Village (Tulehu and Liang), (2) To estimate Readiness Governance of Rural to develop strategy Rural Tourism, (3) to find out the support and participation of local communities to develop strategy rural tourism, (4) To know perception local, national tourism and the relationship to develop rural tourism. The result showed that: (1) Tulehu village had more potencial in rural tourism than Liang village, (2) The local government of Tulehu village more ready to develop rural tourism than Liang, (3) Participation and support from local community in develop rural tourism in both village are good, but if they are compared local community in Tulehu are more engage and much high participate than Liang, (4) Perception of tourism from local and national about rural tourism and tourism obyek is still low.

Keyword: strategy, development, rural tourism
\end{abstract}




\section{Tahkím}

Vol. XIV, No. 2, Desember 2018

\section{Pendahuluan}

Tourism dibelahan dunia telah diakui sebagai salah satu sumber penghasilan devisa oleh beberapa negara. Menurut Global Trend in Coastal Tourism (2007) yang dikutip oleh Akhyaruddin, Trend pariwisata di dunia menghasilkan 10\% dari PDB dan menyerap jumlah tenaga kerja sebanyak 1/12, khusus di dunia berkembang pemasukan devisa utama mereka 2/3 dari negara berkembang di dunia adalah minyak bumi dan pariwisata, dan diproyeksikan bahwa pada Tahun 2020 akan muncul trend dimana kelas menengah baru yang akan melakukan perjalanan 2 kali lebih banyak dibandingkan 20 tahun yang lalu. Menurut UNWTO, pada akhir tahun 2020 jumlah wisatawan dunia akan mencapai 1,6 Milliyar.

Tourism/pariwisata telah menjadi sebuah pengkajian dan disiplin keilmuwan dan telah melahirkan beragam bentuk dan praktik dalam penelitian, kebijakan, dan program dibelahan dunia lain. Ada beberapa term yang saat ini dilakukan oleh para ahli, para peneliti dalam kaitannya dengan Tourism misalnya Cultural dan Heritage Tourism, Ecotourism, Marine Tourism, Rural Tourism, Sustaibnable Tourism.

Rural Tourism (desa wisata) sebagai sebuah konsep dan praktek dapat dihubungkan dengan disiplin keilmuwan lain, misalnya Rural Tourism dihubungkan dengan pembangunan yang diteliti oleh Alice Eruera, ${ }^{1}$ Mlađan Maksimovic, ${ }^{2}$ Roseline Okech $^{3}$, Petrică Ştefan, et.al dihubungkan dengan keterlibatan komunitas lokal seperti penelitian yang dilakukan oleh Bengi Ertuna, ${ }^{5}$ Sacha Reid, ${ }^{6} \mathrm{HE} \mathrm{Li}^{7}$ dihubungkan dengan kompetensi kunci yang dilakukan oleh Noemi Kulchar, ${ }^{8}$ dihubungkan dengan Epsitemology aspek religius yang dilakukan oleh I.C.Alecu, ${ }^{9}$ dihubungkan dengan

\footnotetext{
${ }^{1}$ Alice Eruera, Rural Tourism Development in the eastern Hokianga Area, Ministry Of Tourism/Visa International Tourism Research scholarship, Research Report May 2008, Source: htpp://www.hokianga.co.nz

${ }^{2}$ Mladan Maksimovics, "Theoritical concepts of Rural Tourism and Oppourtunity for develovment in the Republic of Serbia," EMIT UDK, Vol. 3, No.3, 2015.

${ }^{3}$ Roselyne okech, "Rural Tourism as A Sustainable Develovment Alternative: An Analisis with Special reference to Luanda," Kenya Cultur,Year 6-no.03-Aug 2012.

${ }^{4}$ Petrica Stefan, et.al, "Sustainable Development and Implications of Rural Tourism in the development of calarasi country," Journal of settlement and Spatial Planning: htpp://jssp.reviste. ubbcluj.ro.

${ }^{5}$ Bengi Ertuna, et.al, :'Local community Involvement in Rural Tourism development : The Case of kastamonu, Turkey," Pasos, Vol. 10, No. 2, 2012.

${ }^{6}$ Sacha Reid, Community participation In Rural Events : The potencial to develop and Utilize social Capital, School of Tourism \& leisure management The University of Quensland.

${ }^{7}$ He LI, et.al., "Research On Rural Tourism and development of new Rural construction Based On coupling Theory," Interdiciplinary Journal of contemporary Research in Business, Vol.3, No. 10, February 2012.

${ }^{8}$ Noemi KulCSar, "Rural Tourism In Hungaria: The Key Of Competitiveness," Proceeding of FIKUSZ’09 Symposium for Young Researchers 2009.

${ }^{9}$ I.C.Alecu, "Epsitimolgycal Aspect of religious tourism in rural Areas," International Journal of Business,Management and social Science,Vol.2.No.3,2010, h. 59-65.
} 


\section{Tahkím}

Vol. XIV, No. 2, Desember 2018

model jaringan stakeholder untuk membangun Rural Tourism yang dilakukan oleh Elaine Aylward (2009), mengintegrasikan Rural Tourism yang diteliti oleh Gunjan Saxena (2007), pembangunan desa dan strategi yang dilakukan oleh Organisation For Economic Co-operation and Development (OECD) di Paris (1999), dihubungkan dengan paradigma teritorial paradigma baru dalam pembangunan desa oleh Ambosio et.al (2010).

Pariwisata di Indonesia terus dikembangkan bahkan oleh pemerintah pusat yang dianjurkan dan semakin gencar dalam memasarkan wilayahnya masing-masing guna meningkatkan kunjungan wisata lokal, nusantara, dan internasional. Pemerintah pusat juga mendorong setiap daerah untuk bersaing dan meningkatkan fasilitas dan konsep pengembangan wisata di daerah mereka masing-masing dengan cara meningkatkan promosi wisata, mengadakan event-event budaya, olahraga yang dapat meningkatkan citra daerah sebagai sebuah destinasi wisata, dan di sisi lain pemerintah juga membuka peluang untuk adanya desa wisata (Rural Tourism).

Desa Tulehu dan desa Liang adalah dua desa yang termasuk dalam wilayah kecamatan Salahutu kabupaten Maluku Tengah. Kedua desa ini telah menjadi tujuan wisata oleh para wisatawan lokal, nusantara bahkan mancanegara dan telah masuk sebagai sebuah obyek wisata. Untuk desa Tulehu terkenal dengan Air Panas alami, Morea Tulehu yang memiliki perbedaan kebiasaaan makan dengan Morea yang ada di desa Wai, kolam permandian Wailatu yang jernih, Tradisi Abdau dan Kaul Negeri, dan berbagai keunikan alam lainnya yang masih bersifat potensial dan belum dikelola secara profesional dan terintegrasi. Desa Liang terkenal dengan obyek wisata Pantai Liang yang indah, dan pantai ini menurut laman Kotamadya Ambon dijelakan bahwa pernah dinobatkan sebagai pantai terindah oleh UNDP pada tahun 1990 dan telah menjadi incaran para investor.

Berdasarkan uraian di atas makalah ini bertujuan untuk menganalisis (1) mengindentifikasi dan menemukenali potensi-potensi wisata yang dapat mendukung desa Tulehu dan desa Liang dalam menerapkan Strategy Rural Tourism; (2) untuk mengetahui kesiapan aparat dan jajaran pemerintah desa adat Tulehu dan Liang dalam memanfaatkan peluang penerapan Undang-Undang Desa tahun 2014 tentang Desa sebagai sebuah landasan dan kewenangan dalam mengembangkan Strategy Rural Tourism di wilayah mereka; (3) mengetahui tingkat dukungan dan keterlibatan komunitas lokal dalam mendukung desa Tulehu dan desa Liang dalam menerapkan Strategy Rural Tourism; (4) mengetahui persepsi para wisatawan lokal, nasional dan mancanegara tentang desa Tulehu dan desa Liang dalam rangka pengembangan Strategy Rural Tourism. 


\section{Tahkím}

Vol. XIV, No. 2, Desember 2018

\section{Tinjauan Pustaka}

Dalam merangkai bangunan penelitian ini telah ditelusuri beberapa jurnal penelitian tentang Rural Tourism atau Desa Wisata. Adapun para peneliti itu adalah sebagai berikut: penelitian yang dilakukan oleh Bengi Ertuna ${ }^{10}$ yang meneliti relasi antara keterlibatan komunitas lokal dalam pembangunan Rural Tourism di Turkey yang menemukan bahwa diperlukan kerangka kerja yang dihubungkan dengan penilaian terhadap potensi yang ada di satu daerah dalam menciptakan pembangunan Rural Tourism yang berkelanjutan. Peneliti lain yang menjadi rujukan kami yaitu Jean Christophe Dissart, et.al ${ }^{11}$ yang meneliti tentang produk Rural Tourism Production and The Experience menemukan bahwa implikasi untuk perencanaan dan analisis kebijakan sangat diperlukan dalam hal ekonomi, sosial, dan lingkungan yang menjadi hal mendasar dalam wilayah itu dan komunitas mereka. Selanjutnya kami juga membaca peneliti lain yaitu Roselyne Okech, et al. (2012) menemukan bahwa adalah sangat penting untuk mengidentifikasi karakteristik yang sangat signifikan untuk tempat itu dan faktor yang paling kritis untuk area tersebut sebagai sebuah Nation of Rurality.

Untuk lebih menguatkan bangunan argumentasi dan sumber bacaan kami menelusuri penelitian dari belahan dunia lain yaitu penelitian yang dilakukan oleh Noemi Kulcsar ${ }^{12}$ di Hungaria yang meneliti tentang kompetensi kunci dalam Rural Tourism menemukan bahwa: di Hungaria, Rural Tourism adalah daerah yang sedang berkembang, tetapi ada masalah serius dalam faktor daya saing dan faktor kesuksesan. Adapun permasalahan utamanya adalah kompetensi organisasi dan kurangnya budaya kerjasama bisnis. Untuk menyelesaikan masalah ini beliau mengusulkan kerjasama antara Tourism Sulliers dan pemerintah setempat, komunitas lokal yang diasosiasikan dengan DMO. Penelusuran kami berpindah lainnya yaitu penelitian yangh dilakukan oleh Muhammad Rahmani, et al., ${ }^{13}$ yang meneliti tentang pendekatan Rural Tourism di Iran, yang menemukan bahwa sebuah pembangunan Rural Tourism harus direncanakan secara hati-hati dan dikelola dengan baik.

Adapun tujuan pembangunan Rural Tourism harus mempertimbangkan dua dimensi yaitu: tujuan untuk merespon meningkatnya permintaan untuk populasi desa, pembangunan desa wisata untuk menghabiskan waktu senggang mereka dan berekreasi di wilayah desa dan yang kedua yaitu tujuan pembangunan Rural Tourism.

\footnotetext{
${ }^{10}$ Bengi Ertuna, et al., "Local community Involvement in Rural Tourism development: The Case of kastamonu, Turkey, Pasos, Vol.10, No.2, Special Issue, 2012, h. 17-24.

${ }^{11}$ Jean-Christhoper Dissart, et al., "Rural Tourism Production and The experience-Scape," Tourism Analysis, Vol.17, 2013, h .691-704.

${ }^{12}$ Noemi KulCSar, "Rural Tourism In Hungaria: the Key of Competitiveness, Proceeding of FIKUSZ’09 Symposium For Young Researchers 2009, h. 121-127.

${ }^{13}$ Muhammad Rahimi, et al., "Rural Tourism,Approach to Achieve Sustainable Development The Rural in IRAN," Middle East Journal of Scientific Research, Vol. 14, No. 5, h. 720-728.
} 


\section{Tahkím}

Vol. XIV, No. 2, Desember 2018

Untuk lebih mendekatkan dan lebih membumikan konsep Rural Tourism dalam konteks ke-Indonesiaan maka ditelusuri penelitian yang telah ada di Indonesia. Dari hasil penelusuran ditemukan beberapa peneliti, di antaranya penelitian yang dilakukan oleh Nurulitha Andini ${ }^{14}$ yang menemukan bahwa proses pengorganisasian komunitas dalam pengembangan agrowisata ini merupakan siklus yang terdiri dari beberapa tahap, yakni tahap integrasi, pemetaan isu, potensi dan permasalahan, perancangan tindakan bersama, implementasi kegiatan, monitoring dan evaluasi, refleksi, dan adanya feedback untuk kembali melakukan pemetaan isu, potensi dan permasalahan yang terkait dengah Desa Wisata Kembangarum.

Penelitian lain dilakukan oleh I Made Adi Dharmawan, dkk tahun 2014 di daerah Bali tepatnya di di desa Belimbing yang menemukan bahwa berdasarkan hasil analisis faktor internal dan analisis faktor eksternal diidentifikasi potensi yang dimiliki desa wisata di Desa Belimbing Kecamatan Pupuan ditinjau dari: a. Kekuatan (keindahan SDA, Keunikan SDA, kelestarian SDA, kondisi lingkungan yang sejuk, berbagai jenis usaha masyarakat lokal, aksebilitas, sikap masyarakat, pendapatan masyarakat luas, pengamanan pihak aparat), b. Kelemahan (sarana dan prasaranam layanan pegawai pemerintah daerah, keterampilan masyarakat dalam berbahasa inggris yang fasih, manajemen pengelolaan objek, dukungan dana, kebersihan lingkungan, pemanfaatn SDM sebagai pemandu wisata, dan penataan lingkungan), c. Peluang (kunjungan wisatawan, letak strategis dengan obyek wisata lainnya, adanya kepastian hukum, konsep pengembangan wisata alami, lahan pertanian yang dijadikan obyek wisata, kebutuhan wisata alternatif, daerah tujuan wisata bali, terjalinnya kerja sama, dukungan pelaku wisata, otonomi daerah yang diberlakukan pemerintah, nilai budaya masyarakat setempat), d. Ancaman (persaingan dengan daerah lainnya dalam pengembangan desa wisata, berubahnya pola pikir dan perilaku masyarakat, adanya pedagang acung, adanya penduduk pendatang, dan tercemarnya lingkungan). Dan berdasarkan analisis matriks SWOT, maka prioritas yang dapat dilakukan adalah mengembangkan desa wisata dan mempertahankan daya tarik dengan mempersiapkan paket wisata, mempersiapkan rute/peta tracking, dan penataan kawasan.

Penelitian lain dilakukan oleh Kartini La ode Unga ${ }^{15}$ yang menemukan bahwa: Pertama, faktor- faktor internal yang mendukung pengembangan pariwisata kepulauan Banda adalah adanya keragaman antraksi, image kawasan yang sudah terkenal sejak zaman VOC, sifat keterbukaan, keamanan, dan kemudahan mencapai lokasi, sementara yang menghambat adalah belum adanya pusat informasi wisata, sifat terhadap lingkungan rendah, SDM bidang pariwisata masih rendah, dan belum memadainya

\footnotetext{
${ }^{14}$ Nurulitha Andini, Pengorganisasian Komunitas Dalam Pengembangan Agrowisata Di Desa Wisata Study Kasus: Desa Wisata Kembangarum,Kabupaten Sleman," Jurnal Perencanaan Wilayah Dan Kota, Vol. 24, No. 3, Desember 2013, h, 173- 188.

${ }^{15}$ Kartini La Ode Unga, Strategi Pengembangan Kawasan wisata Kepulauan Banda
} 


\section{Tahkím}

Vol. XIV, No. 2, Desember 2018

infrastruktur pendukung. Kedua, faktor eksternal yang mendukung pengembangan pariwisata Kepulauan Banda adalah aksesibilitas, perkembangan teknologi dan informasi wisata, regulasi, serta tingginya potensi dan minat wisatawan, sementara yang menghambat adalah interusi budaya dan pengrusakan lingkungan. Ketiga, strategi prioritas berdasarkan SWOT adalah pengembangan wisata diving dan snorkeling, membangun jaringan dengan wisata lain, bekerja sama dengan agen perjalanan, dan membuat laman khusus.

\section{Metode Penelitian}

Penelitian ini berlokasi di desa Tulehu dan Liang kecamatan Salahutu Kabupaten Maluku Tengah Kecamatan. Penelitian dilakukan selama 4 bulan (juli-oktober) 2016. Yang menjadi responden Penelitian ini seabanyak 50 orang dari dua desa dengan perincian sumber informasi tentang kebijakan desa dari aparat desa 2 orang, ibu- ibu penjual di obyek wisata Liang sebanyak 6 orang, penjual di sekitar air panas Tulehu 4 orang, dan pengunjung obyek wisata pantai Liang dan Air Panas Tulehu serta Batu Kuda sebanyak 38 orang informan.

Tekhnik pengumpulan data yang kami terapkan untuk mendapatkan data dari para responden dengan melakukan wawancara mendalam, dokumentasi, dan pengamatan terhadap obyek wisata.

\section{Potensi yang Bisa dijadikan sebagai modal dalam mengembangkan strategi pengembangan Rural Tourism di desa Tulehu dan Liang Kecamatan Salahutu Kabupaten Maluku Tengah}

Berdasarkan hasil penelitian desa Tulehu memiliki beberapa potensi wisata yaitu: wisata alam, wisata bahari, wisata dudaya, dan memiliki beberapa obyek wisata yang telah berjalan menjadi destinasi wisata Lokal, nasional yaitu Air Panas di dua tempat yang dikunjungi oleh wisatawan lokal (nusantara) dan internasional. Air panas di Tulehu juga masih ada di beberapa titik lainnya di sekitar desa Tulehu hanya saja tidak dikomersilkan dan letaknya ada di pinggir pantai, di sisi lain kami mendapat informasi bahwa di sekitar obyek wisata Batu Kuda di bagian bawah laut ada juga air panasnya dan pemandangan bawah lautnya sangat indah untuk dijadikan tempat (spot) diving.

Potensi lain yang dimiliki oleh desa Tulehu yaitu ada Mata Air Walatu yang bisa dijadikan sebagai tempat mandi bagi anak-anak dan tempat wisata keluarga. Di desa Tulehu juga terdapat binatang yang langka dan endemik di Maluku dan spesial di Tulehu yaitu Morea, sejenis belut sungai yang ukurannya yang sangat besar.

Berdasarkan wawancara yang mendalam dengan aparat desa Tulehu diketahui bahwa kelemahan dan kekurangan potensi wisata yang ada di desa Tulehu adalah sebagai berikut: Pertama, budaya keramah tamahan (hospitality) dan masalah 


\section{Tahkím}

Vol. XIV, No. 2, Desember 2018

kebiasaan melayani tamu; Kedua, kebiasaaan anak muda yang suka mabuk-mabukan dan masih nakal. Dan semua potensi Maluku belum terlalu dikelola dengan profesional dan belum dipromosikan dengan profesional.

Secara teori pemerintah desa Tulehu harus mengembangkan strategi pemasaran pariwisata. Ali Hasan ${ }^{16}$ berpendapat, bahwa strategi pemasaran wisata yang sukses harus dikembangkan berdasarkan dua hal pokok yaitu: Pertama, strategi pemasaran harus dibangun dari lima variable pariwisata, yaitu: (1) Pengembangan lokasi destinasi, (2) Waktu (3) aksestabilitas, (4) Portopolio produk wisata, (5) Edukasi dan sosialisasi bagi semua pemangku kepentingan (stakeholders). Kedua, strategi pemasaran harus dibangun berdasarkan kesadaran bahwa pariwisata memberikan sejumlah manfaat terutama: (1) Terjamin keberlanjutan destinasi pariwisata, (2) Keuntungan secara ekonomi sangat tergantung pada daya tarik lingkungan yang terjaga dan terawat dengan baik, (3) Menghindari atau mengurangi pengeluaran biaya investasi dan biaya operasional yang tidak perlu sebagai akibat terjadinya kerusakan lingkungan, (4) Kepatuhan terhadap peraturan perundang-perundangan yang berlaku, mencegah timbulnya kesan negatif yang berkembang luas, (5) Memenuhi harapan wisatawan yang memiliki kesadaran yang semakin tinggi terhadap isu lingkungan, (6) Menjadikan lingkungan sebagai sumber keunggulan daya saing pariwisata, dan (7) terwujudnya lingkungan bisnis pariwisata (Tourism Business Environtment) yang menguntungkan semua pihak. Pemerintah provinsi, kabupaten Maluku tengah dan pemerintah desa Tulehu dan Liang juga harus memperhatikan tantangan strategis pemasaran pariwisata.

Menurut Ali Hasan (2015:307) ada beberapa tantangan strategi pemasaran pariwisata sebagai berikut:

1. Trend pengembangan Produk

2. Kompetisi destinasi pariwisata

3. Pergeseran trend perjalanan wisata

4. Kesadaran lingkungan

5. Trend konsumen

6. Global warming

7. Krisis global. ${ }^{17}$

Selain harus mengantisipasi tantangan strategi pemasaran pariwisata, pemerintah provinsi, kabupaten, dan pemerintah desa Tulehu dan Liang harus memperhatikan dan mengembangkan strategi promosi wisata. Promosi merupakan variabel khusus pemasaran untuk menarik perhatian wisatawan potensial ke destinasi tertentu dan menikmati berbagai kegiatan yang dirancang dalam pariwisata. Menurut

\footnotetext{
${ }^{16}$ Lihat Ali Hasan, Marketing dan Kasus-Kasus Pilihan (Yogyakarta: CAPS, 2013), h. 306.

${ }^{17}$ Lihat ibid., h. 307.
} 


\section{Tahkím}

Vol. XIV, No. 2, Desember 2018

Ali Hasan secara umum semua promosi wisata memiliki fokus untuk mencapai tujuan pemasaran, sebagai berikut:

1. Meningkatkan pangasa pasar dan pengembangan pasar

2. Meningkatkan jumlah pengunjung

3. Meningkatkan persentase jumlah wisatawan dengan pendapatan tinggi.

4. Meningkatkan pengeluaran wisatawan individu dan masa tinggal lebih lama

5. Mengurangi dampak permintaan musiman (rendah).

6. Meningkatkan pangsa pasar ekowisata.

7. Memastikan distribusi kegiatan wisata yang seimbang ke berbagai daerah;

8. Memposisikan citra Negara/kota destinasi sebagai tujuan wisata yang baik untuk liburan sekolah,hari-hari agama seperti (Idul Fitri, natalan, atau malam tahun baru, dan lain-lain ).

9. Meningkatkan kesadaran akan kekayaan alam dan tempat-tempat bersejarah.

10. Mengintegrasikan dan harmonisasi berbagai produk wisata.

11. Mempromosikan kegiatan internasional seperti olahraga, seni budaya, paralayang, dan lain-lain. ${ }^{18}$

Pemerintah Juga dapat menggunakan beberapa Instrumen promosi wisata yaitu :

1. Laman (Website)

2. E-mail

3. Faks

4. E- news letter

5. Komunitas pariwisata

6. Press kit

7. Brochures

8. Panduan Belanja

9. Panduan Restoran

10. Mass Mailings

11. Hubungan Media

12. Kartu Pos.

Selanjutnya mempertimbangkan model iklan seperti iklan brand, iklan media cetak, iklan poster. Masih berkaitan dengan iklan pemerintah juga harus mempertimbangkan tentang perancangan program periklanan dengan memperhatikan prosesnya dengan seksama dan cermat. Adapun langkah-langkahnya yaitu:

1. Menentukan tujuan periklanan

Fungsi penting periklanan iklan adalah membentuk permintaan dan memengaruhi perilaku pembeli serta membuka peluang bagi perusahaan untuk berkomunikasi

\footnotetext{
${ }^{18}$ Lihat ibid., h. 260.
} 


\section{Tahkím}

Vol. XIV, No. 2, Desember 2018

(menjangkau) orang-orang atau komunitas-komunitas di tempat lain yang jauh dari pabrikasi (destinasi,tempat produksi, atau pengiriman produk).

2. Mengidentifikasi target pasar

Kelompok sasaran harus diprofilkan secara detail baik pelanggan aktual maupun potensial, kebiasaan pembelian, pengguna, atau anggota keluarga yang berpengaruh dalam pengambilan keputusan.

2. Perencanaan iklan kreatif

Tujuan perancangan iklan kreatif adalah untuk menghasilkan eksekusi kreatif dalam menggunakan gambar, simbol, serta kata-kata atau pesan yang menarik dan mengesankan dengan cara yang dinilai paling mampu menembus hambatan pada target pasar.

3. Perencanaan media

Bersamaan dengan perencanaan kreatif adalah perencanaan media, terutama yang berkaitan dengan cara pemrograman dimana iklan akan dilihat, didengar, seleksi media, dan penjadwalan. Pilihan jenis media tersedia banyak untuk pariwisata misalnya:

a. Televisi (pemerintah, swasta nasional maupun daerah )

b. Surat kabar harian, Majalah Bulanan, Mingguan, dan sejenisnya.

c. Banner di search engine internet dan situs web

d. Majalah wisatawan dan majalah wisata minat Khusus;

e. Majalah Bisnis Profesional ( misalnya trade press travel )

f. Brosur wisatawan, panduan, dan direktori pariwisata.

g. Majalah Inhouse (maskapai penerbangan dan hotel yang menjual ruang iklan untuk operator lain ).

h. Radio (stasion nasional dan lokal )

i. Outdoor di situs transfortasi

j. Cinema.

4. Kompabilitas biro iklan

Untuk memudahkan evaluasi pada setiap tahap proses iklan untuk meminimalkan wastage dari satu tahap ke tahap berikutnya, maka marketer harus memantau tingkat konversi antar tahap, mengukur, dan mengembangkan efektivitas kampanye iklan.

Kesiapan Pemerintah Desa Adat Tulehu dan Liang dalam Mengembangkan Strategy Rural Tourism di Tulehu dan Liang Kecamatan Salahutu Kab. Maluku Tengah

Berdasarkan wawancara dengan aparat desa Tulehu dan kunjungan terhadap event Abdauw di desa Tulehu, dapat diketahui bahwa pemerintah desa Tulehu memiliki kesiapan dalam mengembangkan strategi wisata, dalam wawancara ditemukan fakta bahwa karena aparat pemerintah desa/saniri negeri Tulehu memiliki tingkat pendidikan 


\section{Tahkhím}

Vol. XIV, No. 2, Desember 2018

yang relatif tinggi ada beberapa orang yang berkualifikasi S3 dan selebihnya S2 dan S1. Dengan kemampuan manajerial yang mumpuni. Meskipun demikian kami juga mendapatkan bahwa pemerintah desa belum memiliki peraturan desa yang berkaitan dengan pengembangan dan strategi pariwisata di masa depan. Yang telah dilakukan Cultural Tourism yang setiap tahun dilakukan dengan swadaya masyarakat dan partisipasi masyarakat.

Kegiatan Abdauw merupakan sebuah event tahunan yang dilakukan setelah ibadah hari besar islam Idul Adha, kegiatan ini melibatkan ribuan orang dengan berbagai atraksi dan kegiatan untuk menyemarakkan kegiatan tersebut, adapun beberapa atraksi yang ditampilkan dalam kegiatan Abdauw adalah sebagai berikut:

1. Tari Sawath

2. Tari hadrath yang dilakukan oleh sekelompok pemuda sebanyak 30 orang, yang di isi dengan shalawat dan dzikir kepada Allah SWT.

3. Tari penggambaran tentang Kapata Negeri Tulehu

4. Tari Matenu Sahumena.

5. Atraksi Dabush dari Masyarakat Tulehu asal SBT

6. Atraksi Bambu Gila

7. Karnaval dan parade dari berbagai Dusun dengan berbagai Tema (ada penggambaran tentang Kisah Nabi Ibrahim as dan keluarganya, Atraksi tentang kehidupan Nelayan Tulehu.

8. Arak- Arakan Kambing Kurban oleh tetua adat dan ibu-ibu dan masyarakat Tulehu.

9. Tarian Perang Ala Desa Tulehu

10. Dan Puncaknya adalah Atraksi Abdauw.

Menurut pemerintah Desa Tulehu kegiatan Abdauw ini akan diusulkan untuk menjadi agenda tetap dan masuk dalam agenda rutin dari pemerintah provinsi Maluku dan akan dibiaya kegiatannya oleh pemerintah provinsi. Berkaitan dengan pemerintah desa Liang, penulis menemukan bahwa mereka belum terlalu terlibat dalam mengembangkan potensi wisata yang ada di daerahnya, karena obyek wisata pantai Liang pengelolaannya lebih dominan dikendalikan oleh pemerintah provinsi Maluku. Adapun ibu-ibu dan masyarakat yang berjualan di daerah sekitaran obyek wisata yang berjumlah sekitar 150 orang terlibat dalam kegiatan dan mendukung kegiatan pariwisata Liang dengan menyediakan makanan, minuman dan juga fasilitas dan peralatan yang seadanya yang diperlukan untuk berenang, naik perahu, banana Boat, dan tempat duduk berupa terpal untuk duduk di pantai Liang. Dari segi Manajemen dan keterlibatan dalam pengelolaan obyek wisata ada baiknya pemerintahan desa Liang mengembangkan obyek wisata lain, sambil memperbaiki kerja sama dengan pemerintah daerah provinsi dan Maluku tengah dalam rangka semakin meningkatkan kualitas dan kuantitas pelayanan di obyek wisata Liang dan semakin mengembangkan fasilitas, sarana dan prasana pariwisata yang dibutuhkan dalam obyek wisata Liang. 


\section{Tahkím}

Vol. XIV, No. 2, Desember 2018

\section{Dukungan dan tingkat keterlibatan komunitas lokal dalam rangka mengembangkan Strategy Rural Tourism di Tulehu dan Liang Kecamatan Salahutu Kab. Maluku Tengah}

Berdasarkan hasil penelitian di desa Tulehu terkait keterlibatan masyarakat dalam mendukung pariwisata di daerahnya sudah cukup bagus, bahkan obyek wisata air panas Tulehu dikelola secara pribadi oleh masyarkat Tulehu dan mereka memberikan kontribusi kepada pemerintah desa setiap bulannya walaupun menurut aparat desa masih sedikit, keberadaan obyek wisata air panas Tulehu menjadi sebuah magnet dan juga sumber pendapatan bagi masyakat sekitar misalanya ada beberapa ibuibu yang berjualan asongan di sekitar obyek wisata, beberapa pemuda menjadi tukang parkir dan pengelola obyek air panas tersebut.

Partisipasi masyakarat Tulehu sangat terasa pada saat dilaksanakannya Karnaval Abdauw setelah hari besar islam Idul Adha, dimana masyarakat memberikan sumbangan, ikut berpartisipasi menjadi penari, menyuguhkan atraksi, menjaga keamanan, pemuda-pemuda terlibat sebagai laskar Karnaval abdauw, dan lain sebagainya, dan kegiatan tersebut juga di hadiri oleh ribuan masyarakat baik dari Tulehu, dan masyarakat sekitar Ambon, bahkan ada dari Ternate serta dari mancanegara.

Di desa Liang partisipasi dan keterlibatan masyarakat dalam mendukung pariwisata di obyek wisata Liang juga terasa, ada sekitar 150 Orang pelaku usaha kecil menengah di kawasan obyek wisata, disamping mereka berjualan dan menyediakan jasa lainnya seperti menyewakan tempat duduk, sewa ban, dan jasa parkir, menyedikan air untuk mandi di toilet karena tidak tersedia air bersih, para ibu-ibu ini juga bertugas dan melakukan kerja-kerja yang mulia yaitu membersihkan sampah- sampah di sekitar tempat mereka berjualan. Dan ini sudah mereka lakukan selama puluhan tahun.

\section{Persepsi wisatawan lokal, nasional tentang Desa Tulehu dan Desa Liang dalam rangka mengembangkan Strategy Rural Tourism}

Dalam hasil wawancara dengan para informan, mereka berpendapat bahwa obyek wisata di kedua desa ini sangat menarik, indah, dan sangat natural dan layak untuk dikembangkan menjadi destinasi wisata yang unggul. Adapun masalah dan kekurangan obyek wisata dari dua desa ini yaitu berkaitan dengan beberapa hal sebagai berikut:

1. Sarana dan prasana mendasar yang ada di obyek wisata seperti: belum adanya mushalla, toilet yang sangat jorok dan sedikit jumlahnya, petunjuk arah dan keterangan yang belum ada.

2. Masalah kebersihan

3. Masalah keamanan dan kenyamanan di obyek wisata.

4. Akses jalan menuju obyek wisata yang masih banyak rusak. 


\section{Tahkím}

Vol. XIV, No. 2, Desember 2018

5. Masalah kumuhnya tempat makan karena hanya dibuat seadanya oleh para penjual dan bukan desain dari pemerintah dan bukan dibangun oleh pengelola.

6. Pengelola yang belum terlalu professional.

7. Budaya Melayani

8. Sopan santun dalam melayani tamu.

9. Dan lain-lain.

\section{Kesimpulan}

Berdasarkan hasil penelitian dan pembahasan di atas dapat disimpulkan sebagai berikut:

1. Desa Tulehu memiliki potensi wisata yang lebih siap dalam untuk menjadi desa wisata. Dibandingkan dengan desa Liang.

2. Kesiapan pemerintah desa Tulehu dalam pengelolaan desa wisata lebih siap dibandingkan dengan Desa Liang.

3. Keterlibatan masyarakat dan komunitas di dua desa sangat bagus dalam pengelolaan desa Wisata.

4. Persepsi Wisatawan lokal dan Nusantara terhadap pengelolaan obyek wisata di desa Tulehu dan Liang masih rendah.

\section{DAFTAR PUSTAKA}

Alecu, I.C. "Epsitimolgycal Aspect of religious tourism in rural Areas," International Journal of Business,Management and social Science,Vol. 2, No. 3, 2010.

Andini, Nurulitha. "Pengorganisasian Komunitas Dalam Pengembangan Agrowisata Di Desa Wisata Study Kasus: Desa Wisata Kembangarum,Kabupaten Sleman. Jurnal Perencanaan Wilayah Dan Kota, Vol. 24, No. 3, Desember 2013.

Eruera, Alice. Rural Tourism Development in the eastern Hokianga Area, Ministry Of Tourism/Visa International Tourism Research scholarship, Research Report May 2008, Source: htpp://www.hokianga.co.nz.

Dissart, Jean-Christhoper, et al. "Rural Tourism Production and The experienceScape," Tourism Analysis, Vol. 17, 2013.

Ertuna, Bengi, et.al. "Local community Involvement in Rural Tourism development : The Case of Kastamonu, Turkey," Pasos, Vol. 10, No. 2, 2012.

Hasan, Ali. Marketing dan Kasus-Kasus Pilihan, Yogyakarta: CAPS, 2013. 


\section{Tahkím}

Vol. XIV, No. 2, Desember 2018

He LI et.al. "Research On Rural Tourism and development of new Rural construction Based on Coupling Theory, Interdiciplinary Journal of contemporary Research in Business, Vol. 3, No. 10, February 2012.

Unga, Kartini La Ode. Strategi Pengembangan Kawasan wisata Kepulauan Banda.

KulCSar, Noemi. "Rural Tourism In Hungaria: The Key Of Competitiveness," Proceeding of FIKUSZ'09 Symposium for Young Researchers 2009.

L.I., He, et.al. "Research On Rural Tourism and development of new Rural construction Based On coupling Theory," Interdiciplinary Journal of contemporary Research in Business, Vol.3, No. 10, February 2012.

Maksimovics, Mladan. "Theoritical concepts of Rural Tourism and Oppourtunity for develovment in the Republic of Serbia," EMIT UDK, Vol. 3, No.3, 2015.

Rahimi, Muhammad, et al., "Rural Tourism,Approach to Achieve Sustainable Development The Rural in IRAN," Middle East Journal of Scientific Research, Vol. 14, No. 5.

Stefan, Petrica. et.al, "Sustainable Development and Implications of Rural Tourism in the development of calarasi country," Journal of settlement and Spatial Planning: htpp://jssp.reviste. ubbcluj.ro.

Okech, Roselyne. "Rural Tourism as A Sustainable Develovment Alternative: An Analisis with Special reference to Luanda," Kenya Cultur,Year 6-no.03-Aug 2012.

Reid, Sacha. Community participation In Rural Events: The potencial to Develop and Utilize social Capital, School of Tourism \& Leisure Management The University of Quensland. 